Génét. Sél. Evol., 1987, 19 (1), 1-8

\title{
A cytogenetic investigation on peripheral blood lymphocytes of cattle affected by enzootic bovine leukemia
}

\author{
A. GALLI *, L. CARBONI *, A. GHIDONI ** \\ * Consorzio Provinciale Fecondazione Artificiale, Via Borgo Palazzo 128, 24100 Bergamo, Italia \\ ** Dipartimento di Genetica e di Biologia dei Microrganismi, Università degli Studi di Milano, \\ Via Celoria 26, 20133 Milano, Italia
}

\begin{abstract}
Summary
This cytogenetic study involved 10 Agar-Gel Immunodiffusion (AGID) test-positive cows without lymphocytosis, 6 similar subjects with lymphocytosis and 10 healthy subjects. No appreciable differences were found for aneuploid rates or chromosome aberrations. However, a higher frequency of polyploid cells was consistently observed among subjects affected by enzootic bovine leukemia without lymphocytosis (average : $4.8 \mathrm{p} .100$ ) as compared with healthy controls (average: $1.5 \mathrm{p} .100)$. The lymphocytes in both groups were stimulated by phytohemagglutinin. A higher frequency of polyploid cells was not found among subjects affected by enzootic bovine leukemia with lymphocytosis, whose lymphocyte cultures were stimulated by concanavalin $\mathrm{A}$.
\end{abstract}

Key words: Chromosome, enzootic bovine leukemia, Italian Friesian cattle.

\author{
Résumé \\ Etude cytogénétique de lymphocytes du sang périphérique \\ de bovins atteints de leucémie enzootique
}

L'étude cytogénétique concernait 10 vaches positives pour le test AGID (immunodiffusion en gel d'agar) et exemptes de lymphocytose, 6 sujets similaires atteints de lymphocytose et 10 sujets sains. On n’a pas trouvé de différence appréciable pour les taux d'aneuplö̈die ou les aberrations chromosomiques. Cependant, on a observé une fréquence plus élevée de cellules polyploïdes chez les sujets atteints de leucémie bovine enzootique sans lymphocytose (moyenne : 4,8 p. 100) que chez les témoins sains (moyenne : 1,5 p. 100). Dans les 2 groupes, les lymphocytes sont stimulés par la phytohémagglutinine. On n’a pas trouvé une fréquence plus élevée de cellules polyplö̈des chez les sujets atteints de leucémie bovine enzootique avec lymphocytose, dont les cultures lymphocytaires sont stimulées par la concanavaline A.

Mots clés : Chromosome, leucémie bovine enzootique, bovins Frisons d'Italie. 


\section{Introduction}

Enzootic bovine leukemia (EBL), a lymphosarcomatous-like chronic disease caused by a retroviral agent (Bovine Leukemia Virus, BLV) has been the object of few cytogenetic investigations. A submetacentric supernumerary chromosome and other sporadic anomalies concerning chromosome condensation were found in lymph nodes of a Holstein bovine affected by lymphosarcoma (BASRUR et al., 1964). Various non specific chromosomal anomalies were also observed in peripheral blood lymphocytes (Gustavsson \& Rockborn, 1964 ; Gustavsson, 1966 ; Hare et al., 1967 ; Martin \& Flanagan, 1967). However, a specific robertsonian translocation involving chromosomes 1 and 29 was observed (GUSTAVSSON \& ROCKBORN, 1964) in tumour cells of cattle affected by lymphatic leukemia, and a higher frequency of chromosomal anomalies were found (Lombard, 1968 ; FERrer, 1980) to be associated with this pathologic situation. Weinhold (1970) demonstrated a relatively high percentage of hyperploid cells in bovine leucosis. In a more recent study only sporadic structural chromosomal anomalies were found (GRIMOLDi et al., 1983) in peripheral blood lymphocytes of cows clinically healthy, affected by EBL. Hypodiploid cells metacentric and submetacentric chromosomes were found in cows affected by tumoral forms of bovine leukosis. These findings suggest, in accord with another study (FERRER, 1980), that the persistent lymphocytosis may be a benign response to the viral agent involved in this cattle disease. Guo \& Guo (1983) showed some chromosome anomalies in Bovine leucosis, e.g. hyperploid and hypoploid cells, chromatid and isochromatid aberration, etc., especially significantly diminished nucleolus organizer regions (NORs), and significantly higher sister chromatid exchanges (SCE).

The present investigation was undertaken to obtain more cytogenetic information on cows affected by EBL with or without persistent lymphocytosis.

\section{Material and methods}

The investigation concerned 26 cows of the Italian Friesian breed from 2 herds located near Bergamo in The Northern Po valley (Italy). The herds are similarly equipped and under similar management. All subjects were tested twice, with 12 months' interval, by the agar gel immunodiffusion test (AGID test) for bovine leukosis virus of Bex et al. (1979). On all subjects the leucocyte formula was determined twice, with one month's interval, on peripheral blood smears, after staining by the standard May-Gruenwald-Giemsa method (BECCARI \& MAZZI, 1966), in order to identify subjects with or without relative persistent lymphocytosis.

The 26 cows under study were grouped as follows :

1. Ten healthy subjects as a control (Group $\mathrm{H}$ ).

2. Ten AGID test-positive subjects without persistent relative lymphocytosis (Group L1).

3. Six AGID test-positive subjects with persistent relative lymphocytosis (Group L2). 
Peripheral blood cultures were set up according to standard procedures (after MoOREHEAD et al., 1960) with the following details : in each vessel suitable to $8 \mathrm{ml}$ cultures were mixed the lymphocyte fraction of $8 \mathrm{ml}$ venous blood, $13 \mu \mathrm{g}$ phytohemagglutinin (type M, Gibco), or $10 \mu \mathrm{g}$ concanavalin A (IV-S, Sigma) and TC 199 medium with 20 p. 100 autologous serum. The concanavalin A mitogen was used in place of phytohemagglutinin for subjects of Group L2 where the latter achieved only a poor stimulation. Cultures were arrested at $72 \mathrm{hr}$. Two hours before collecting cells, colcemid (Gibco) at $.01 \mu \mathrm{g} / \mathrm{ml}$ (final concentration) was added to each culture. Slides were made according to the standard air drying procedure and stained with a $4.5 \mathrm{p} .100$ Giemsa solution, buffered at $\mathrm{pH}$ 6.8. An average of about 125 metaphases were analyzed for each subject. Cells lacking 2 or more chromosomes were not considered in the analysis.

The $C$ and $G$ banding patterns of cells with the robertsonian translocation $1 / 29$ were obtained following the procedures of SUMNER (1972) modified by PoPESCU (1975), and of Seabright (1971) modified by Hageltorn \& Gustavsson (1973), respectively, studied by PoPESCU (1975).

\section{Results}

The leucocyte formulas of all subjects analysed, as obtained from peripheral blood smears, are shown in table 1 . While group $\mathrm{H}$ and L1 showed a typical leucocyte formula, Group L2 had relatively higher values for lymphocytes (mostly at the expense of neutrophile leucocytes). This is a rather common finding among subjects with lymphocytosis (STOEBER \& Gruender, 1977).

TABLE 1

Leucocyte formulas found in healthy subjects $(H)$, in AGID test-positive subjects without persistent relative lymphocytosis (Group L1) and AGID test-positive subjects with persistent relative lymphocytosis (Group L2). Mean values ( $\tilde{x})$ and standard errors (S.E.) are given.

\begin{tabular}{|c|c|c|c|c|c|c|}
\hline \multirow{3}{*}{ Parameters } & \multicolumn{6}{|c|}{ Groups } \\
\hline & \multicolumn{2}{|c|}{$\mathbf{H}$} & \multicolumn{2}{|c|}{ L1 } & \multicolumn{2}{|c|}{ L2 } \\
\hline & $\overline{\mathbf{x}}$ & S.E. & $\overline{\mathbf{x}}$ & S.E. & $\overline{\mathbf{x}}$ & S.E. \\
\hline Lymphocytes & 48.65 & 2.56 & 40.50 & 3.43 & 64.08 & 2.10 \\
\hline Monocytes . & 6.20 & 0.53 & 6.45 & 0.80 & 3.66 & 0.48 \\
\hline Neutrophile leucocytes & 37.50 & 2.75 & 44.35 & 2.06 & 24.58 & 2.34 \\
\hline Eosinophile leucocytes & 6.35 & 1.39 & 7.90 & 1.62 & 7.08 & 1.34 \\
\hline Basophile leucocytes $\ldots \ldots \ldots$ & 0.95 & 0.31 & 0.80 & 0.10 & 0.58 & 0.15 \\
\hline
\end{tabular}

The results of the cytogenetic investigation are reported in table 2. By comparing AGID test-positive and control subjects, significant differences at the chromosomal 
level were not found except for a higher percentage of polyploid cells (4.8-9 p. 100) among Group L1 (tabl. 3). Other observations concerning the frequency of aneuploid cells, chromosomal breaks or gaps and obvious chromosomal rearrangements, failed to disclose any significant difference between any of the groups examined in this regard.

TABLE 2

Summarized frequencies of chromosomal anomalies (percentages in parenthesis) found in healthy subjects $(H)$, in AGID test-positive subjects without persistent relative lymphocytosis (Group L1) and AGID test-positive subjects with persistent relative lymphocytosis (Group L2).

\begin{tabular}{|c|c|c|c|}
\hline \multirow{7}{*}{$\begin{array}{l}\text { Polyploid cells }(\%) \ldots \ldots \\
\text { Aneuploid cells }(\%){ }^{(1)} \ldots \ldots \ldots \\
\text { Cells with breaks }(\%)^{(2)} \ldots \ldots \ldots \ldots \\
\text { Cells with robertsonian }{ }^{(2)} \ldots \ldots \ldots \ldots \ldots \\
\text { Cells with dicentric rings } \ldots \ldots \text {. } \ldots \ldots \text {. } \ldots \ldots \text {. } \ldots \ldots \text {. }\end{array}$} & \multicolumn{3}{|c|}{ Groups } \\
\hline & $\begin{array}{c}H \\
(N=10)\end{array}$ & $\begin{array}{c}\mathrm{L1} \\
(\mathrm{N}=10)\end{array}$ & $\begin{array}{c}\mathrm{L} 2 \\
(\mathrm{~N}=6)\end{array}$ \\
\hline & $19(1.5)$ & $58(4.8)$ & $11(1.5)$ \\
\hline & $14(1.1)$ & $16(1.3)$ & $12(1.6)$ \\
\hline & $49(3.8)$ & $41(3.4)$ & $11(1.5)$ \\
\hline & $4(0.3)$ & $5(0.4)$ & $4(0.5)$ \\
\hline & $0(0)$ & $0(0)$ & $0(0)$ \\
\hline Cells with gaps $\ldots \ldots \ldots \ldots \ldots \ldots \ldots$ & 34 & 32 & 20 \\
\hline No. of cells examined $\ldots \ldots \ldots \ldots$ & 1302 & 1218 & 753 \\
\hline
\end{tabular}

\section{TABLE 3}

Comparative frequencies of polyploid cells found in the cytogenetic study regarding healthy (Group $H$ ) and $A G I D$ test-positive cattle without persistent relative lymphocytosis (Group L1). The two groups have been compared with two non-parametric tests (rank sum WiLcoxon's test and MANN-WhITNEY's test). The two groups are resulted different $(P<0.05)$.

\begin{tabular}{l|c|c|c|c|c}
\hline \multicolumn{3}{c|}{ Group H } & \multicolumn{3}{c}{ Group L1 } \\
\hline Subjects & $\begin{array}{c}\text { Polyploid } \\
\text { cells }\end{array}$ & $\begin{array}{c}\text { Normal } \\
\text { cells }\end{array}$ & Subjects & $\begin{array}{c}\text { Polyploid } \\
\text { cells }\end{array}$ & $\begin{array}{c}\text { Normal } \\
\text { cells }\end{array}$ \\
\hline L 98 & 1 & 129 & L 45 & 3 & 99 \\
L 99 & 3 & 126 & L 48 & 4 & 103 \\
L 132 & 7 & 127 & L 50 & 6 & 107 \\
L 133 & 1 & 120 & L 51 & 3 & 120 \\
L 135 & 1 & 130 & L 125 & 13 & 129 \\
L 136 & 1 & 135 & L 126 & 9 & 121 \\
L 147 & 2 & 126 & L 127 & 7 & 126 \\
L 148 & 1 & 137 & L 128 & 6 & 127 \\
L 149 & 0 & 137 & L 129 & 4 & 122 \\
L 150 & 2 & 133 & L 130 & 3 & 132 \\
\hline \hline
\end{tabular}




\section{Discussion}

Standard values regarding the frequency of chromosomal anomalies in bovine leucocyte cultures stimulated in vitro are not available in the literature. The frequency of numerical anomalies in the healthy subjects, Group $\mathrm{H}$ (polyploid cells $1.5 \mathrm{p}$. 100, aneuploid cells 1.1 p. 100) is not higher than found with humans (LitTLEFIELD \& GoH, 1973).

The finding of a higher percentage of polyploid metaphases in lymphocytes of Group L1 subjects (AGID test-positive, without lymphocytosis) may be regarded as a consequence of the viral infection, as was suggested by HARE et al. (1964).

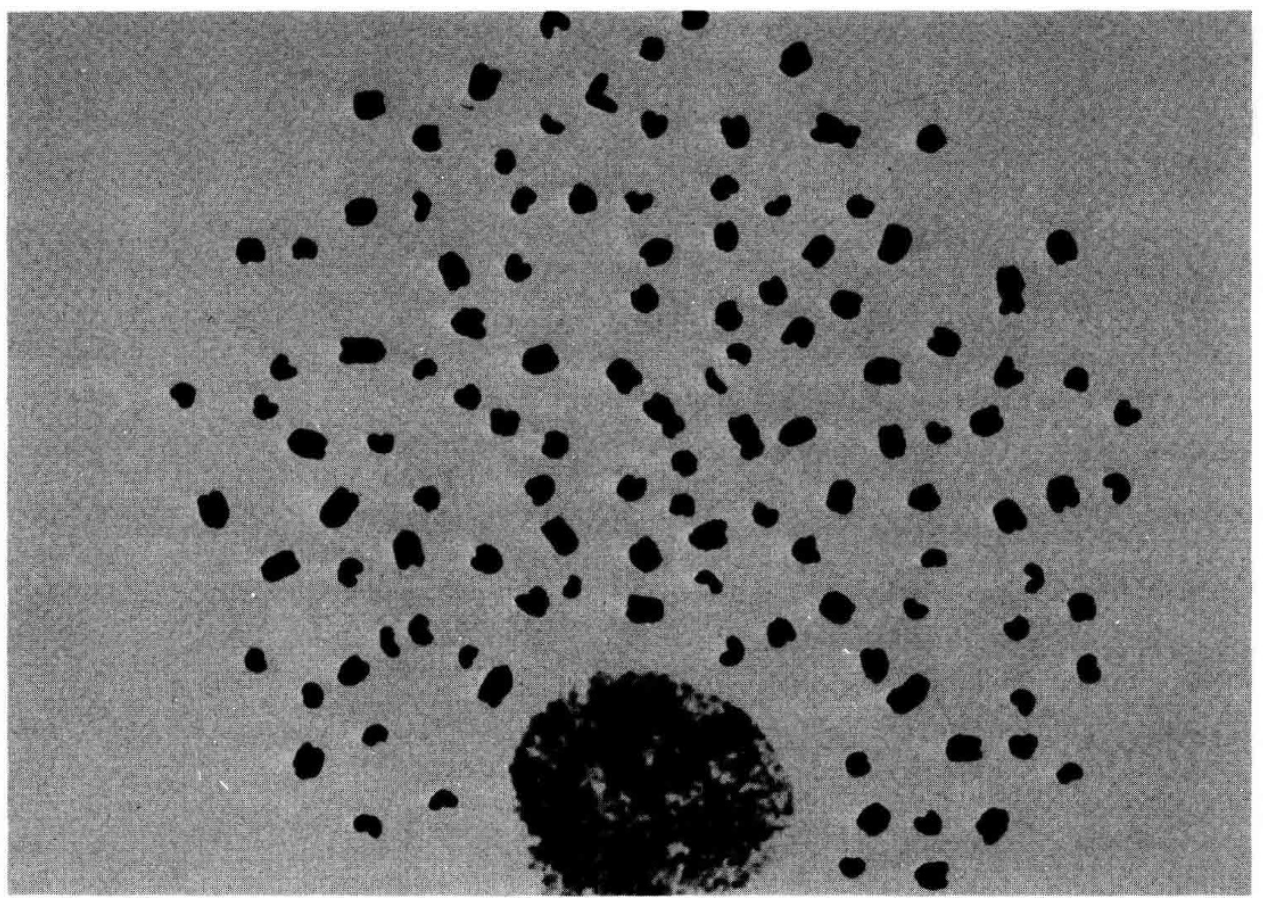

Fig. 1

A tetraploid metaphase with 120 chromosomes, obtained from a leukotic cow without lymphocytosis (L 125), stained with Giemsa.

The frequencies of cells with breaks (3.4-3.8 p. 100), after stimulation with phytohemagglutinin, may be regarded as relatively high if compared with observations made on human cultured lymphocytes, where most investigators reported values of $1 \mathrm{p}$. 100 or less (Evans et al., 1979 ; Lloyd et al., 1980 ; Alicata et al., 1981). However, these values were found for both AGID test-positive or healthy subjects, thus possibly 
resulting from our culture conditions. The frequency of breaks in peripheral blood lymphocytes of subjects in Group 2 (AGID test-positive, with lymphocytosis) was, however, relatively lower ; in this case the stimulation was achieved with concanavalin A. As an explanation, one could suggest that the different mitogens may have stimulated different subsets of T-lymphocytes with varying effects of the consequent stimulation on other subsets of B-lymphocytes, as suggested by KRISTENSEN et al. (1982). Until this point is made clear, the analysis of cytogenetic data should properly consider the existence of this kind of heterogeneity.

The frequency of robertsonian translocations was not found to differ statistically among the 3 groups examined, although Gustavsson \& RocKBorn (1964) showed that some such rearrangements may be typical of lymphoid leukemia. The observations concerning robertsonian translocation made in the present investigation seem to exclude the hypothesis that this type of rearrangements is relevant to the etiology or the progression of enzootic bovine leucosis, at least in the subjects examined by us. All of the robertsonian translocations observed by us involved apparently chromosomes 1 and 29.

$1 / 29 \quad 1$

26

27

28

29

G. banding
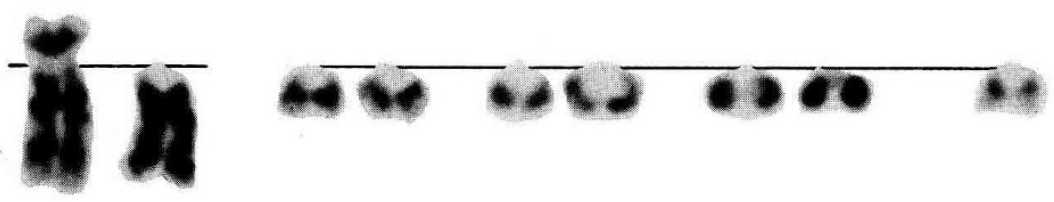

C banding

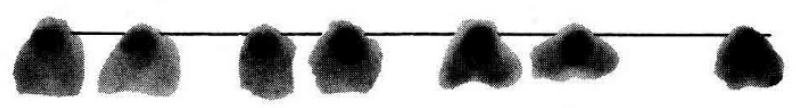

Fig. 2

$A$ robertsonian translocation $1 / 29$, studied with banding patterns $(G$ and $C$ ), obtained from a leukotic cow without lymphocytosis (L 127).

There were no marked differences in the frequencies of aneuploid cells observed in the healthy subjects (H) and in the AGID test-positive subjects (L1).

An average of 1.2 p. 100 of aneuploid cells was found in the 3 tested groups. This result is not comparable with that of BASRUR et al. (1964), who found a high rate of aneuploid cells (above 60 p. 100) in lymph node leucocyte cultures from one subject affected by lymphosarcoma.

Group H (healthy) and Group L1 (AGID test-positive, without lymphocytosis) both were stimulated with phytohemagglutinin ; in this comparison notable differences were not found except for polyploid cells rates. 
The poor stimulation of lymphocytes by the phytohemagglutinin in AGID testpositive subjects with persistent lymphocytosis is parallel to similar stimulation difficulties in human leukemic subjects, perhaps as a consequence of a deficient immune response that characterizes such patients (BERnard et al., 1964 ; Chiorazzi et al., 1979 ; UMEDA et al., 1982 ; GHIDONI et al., 1984).

\section{Conclusion}

A higher frequency of polyploid cells was observed in AGID test-positive subjects without persistent relative lymphocytosis (Group L1).

A high frequency of chromosomal anomalies was not found in AGID test-positive cows with persistent relative lymphocytosis (Group L2). Persistent lymphocytosis is therefore probably a benign reactive condition of a lymphoproliferative kind as was suggested by Ferrer (1980) and Grimoldi et al. (1983).

Received October 14, 1985.

Accepted September 3, 1986.

\section{Acknowledgements}

The authors wish to thank Dr. M. BosISIo and Prof. M. SARI for technical assistance.

\section{References}

Alicata P., Biondi O., Cantarella T., De luca B., Ghidoni A., Motra S., Politi G., Radice P., Sammartano F., 1981. Variabilità individuale nella frequenza di aberrazioni cromosomiche in soggetti professionalmente esposti al rischio di radiazioni ionizzanti. Atti Ass. Genet. Ital., 28, 9-12.

Basrur P.K., Gilman J.P.W., McSherry B.J., 1964. Cytological observations on a bovine lymphosarcoma. Nature, 25, 368-371.

Beccari N., Mazzi V., 1966. Studio speciale delle cellule dei tessuti. In : Beccari N., Mazzi V. (ed.), Manuale di tecnica microscopica, 129-222, Casa Editrice Dr. Francesco Vallardi Società Editrice Libraria, Milano.

Bernard C., Geraldes A., Boiron M., 1964. Action de la phytohemagglutinine in vitro sur les lymphocytes de leucémies lymphoïdes chroniques. Nouv. Revue Fr. Hémat., 4, 69.

Bex F., Bruck C., Mammerickx M., Portetelle D., Ghysdael J., Cleuter Y., Leclerce M., Dekegel. D., Burny A., 1979. Humoral antibody response to bovine leukemia virus infection in cattle and sheep. Cancer Res., 39, 1118-1123.

Chiorazzi N., Fu S.M., Montazen G., Kunkel H.G., Raf R., Gee T., 1979. T cell help defect in patients with chronic lymphocytic leukemia. J. Immun., 122, 1087-1090. 
Evans H.J., Buckton K.E., Hamilton G.E., Carothers A., 1979. Radiation-induced chromosome aberrations in nuclear-dock-yard workers. Nature, 277, 531-534.

Ferrer J.F., 1980. Bovine lymphosarcoma. Adv. Vet. Sci. Comp. Med., 24, 1-68.

Ghidoni A., Privitera E., Raimondi E., Rovini D., Illeni M.T., Cascinelli N., 1984. Sister chromatid exchanges in phytohemagglutinin-stimulated lymphocytes of nonfamilial cutaneous malignant melanoma patients. In : RAYmond R.T., Hollander A. (ed.), Sister chromatid exchanges, 855-858, Plenum Publishing Corporation, New York.

Grimoldi M.G., Poli G., Sartorelli P., Caldora C., Oldani L., Locatelli A., 1983. Karyotype analysis of lymphocytes from cattle at different stages of bovine leukemia virus infection. Br. Vet. J., 139, 240-246.

Guo A., Guo D., 1983. The chromosomes of bovine leukemia. Acta Vet. et Zootech. Sinica, 14, 201-207.

Gustavsson I., 1966. Chromosome abnormality in cattle. Nature, 211, 865-866.

Gustavsson I., Rockborn G., 1964. Chromosome abnormality in three cases of lymphatic leukemia in cattle. Nature, 203, 990.

Hageltorn M., Gustavsson I., 1973. Giemsa staining patterns for identification of the pig mitotic chromosomes. Hereditas, 75, 144-146.

Hare W.C.D., McFeely R.A., Abt D.A., Feirman J.R., 1964. Chromosomal studies in bovine lymphosarcoma. J. Natl. Cancer Inst., 33, 105-118.

Hare W.C.D., Yang Tsu-Ju, McFeely R.A., 1967. A survey of chromosomes finding in 47 cases of bovine lymphosarcoma (leukemia). J. Natl. Cancer Inst., 38, 383-392.

Kristensen F., Kristensen B., Lazary S., 1982. The lymphocyte stimulation test in veterinary immunology. Vet. Immun. Immunop., 3, 203-277.

LrTtlefield L.G., GoH K.O., 1973. Cytogenetic studies in control men and women. I. Variations in aberration frequencies in 29,709 metaphases from 305 cultures obtained over a three-year period. Cytogenet. Cell Genet., 12, 17-34.

Lloyd D.C., Purrot R.J., Reeder E.J., 1980. The incidence of unstable chromosome aberrations in peripheral blood lymphocytes from unirradiated and occupationally exposed people. Mutat. Res., 72, 523-532.

Lombard C., 1968. Les leucoses des mammifères. In : Lombard C. (éd.), Les leucoses animales, 9127, I.N.R.A., Paris.

Martin W.B., Flanagan M., 1967. Karyotype analysis of leucocytes from normal and lymphosarcomatous cattle (Bos Taurus). Br. J. Cancer, 21, 137-143.

Moorhead P.S., Nowell P.C., Mellman W.J., Battips M., Hungerford D.A., 1960. Chromosomes preparations of leukocytes cultured from peripheral blood. Exp. Cell Res., 20, 613-616.

Popescu C.P., 1975. L'étude du caryotype bovin (Bos Taurus L.) par les méthodes de bandes. Ann. Biol. Anim. Bioch. Biophys., 15, 751-756.

SeABright M., 1971. A rapid banding technique for human chromosomes. Lancet, 2, 971-972.

Stoeber M., Gruender H.D., 1977. Apparato circolatorio. In : Rosenberger G. (ed.), L'esame clinico del bovino, 114-182, Editrice Essegivi, Piacenza.

Sumner A.T., 1972. A simple technique for demonstrating centrochromatin. Exp. Cell. Res., 75, 304-306.

Umeda J., Hara T., Koseki K., Kobayashi K., Akaza H., Niujima T., 1982. Diminished helper-Tlymphocyte function in cancer patients. Cell. Mol. Biol., 28, 67-71.

Weinhold E., 1970. Chromosomenuntersuchungen bei der Rinderleukose. Ith Europ. Kolloqu. Zytogenetik in Veterinarmedizin u. Saugetierkd., 12-13 Oct., Giessen. 119-126. Inst. für Erpathol. und Zuchthygiene. 